\title{
Changes in Productive Organisation, Outsourcing and Multiservice Companies (A New Workers' Category: "Sub-Ceded" Worker)
}

\author{
Arántzazu Vicente-Palacio* \\ Labour Law and Social Security University, University Jaume I of Castellón, Castellón, Spain \\ Email: Arantzazu.Vicente@uji.es
}

How to cite this paper: Vicente-Palacio, A. (2018). Changes in Productive Organisation, Outsourcing and Multiservice Companies (A New Workers' Category: "Sub-Ceded" Worker). Beijing Law Review, 9, 255-274.

https://doi.org/10.4236/blr.2018.92017

Received: April 14, 2018

Accepted: June 9, 2018

Published: June 12, 2018

Copyright (c) 2018 by author and Scientific Research Publishing Inc. This work is licensed under the Creative Commons Attribution International License (CC BY 4.0).

http://creativecommons.org/licenses/by/4.0/

\begin{abstract}
The outsourcing phenomenon has increased considerably in recent years, and the appearance and rapid spread of multiservice or all-round management companies have, in turn, substantially contributed to this phenomenon. All this has been made possible by numerous economic and legal causes, with the Employment Law still having to react to the precariousness of the legal statute of this new worker category: the "subceded" worker by finishing with some proposals for which the lawmaker takes his/her responsibility and puts an end to today's harmful legal anomie.
\end{abstract}

\section{Keywords}

Outsourcing, Subcontracting, Collective Bargaining, Sub-Ceded, Precariousness, Subrogation

\section{Changes in Access to Employment as a Result of the Transformation in Business Productive Organisation}

The way to access employment in Spain has profoundly evolved in more than 36 years since Law 8/1980, of 10 March, was enacted, by which the (first) Workers Statute (WS) was passed. Changes have affected forms of contracting, particularly its part-time aspect, but above all, they have also affected many dimensions of the work contract model: third parties enter the traditional bilateral logic of work contracts (part-time companies); part-time contracting increasingly being extended as opposed to conventional full-time contracting; private subjects in-

*ORCID: 0000-0002-6559-4386. 
tervening in employment management (private job placement agencies); and very importantly, the changes made in business organisation systems that have gone from the traditional Fordist model, which includes all the production process phases, to an increasingly decentralised company via outsourcing or subcontracting works and services, which gives way to the so-called "network company".

Despite these major changes, the reaction of the Employment Law has clearly proven insufficient. Although many legal reforms have taken place, stating that, in essence, we have exactly the same protective mechanisms as we had 40 years ago, or at least we face these changes with the same legal outlines. The Employment Law has always centred most of its attention on "safe employment" both when starting and leaving employment: on the causality of employment and on the necessary casual character, and also on contractual extinction; firstly, in the bilateral contractual relation area, and then in the three parties relationship area after part-time companies (PTC) became legal in 1994. While we were anchored to this struggle between flexibility and safety in labour management, we did not realise that a transformation in the way to do business organisation was underway, which has made this debate unnecessary or has, at least, played it down.

This transformation has been operated by generalising the subcontracting of all those works and services, especially services, which can be placed in external hands without compromising the company's know-how, and this is most evidently manifested in the form that multiservice companies take. Companies are no longer a more or less organised whole with the technical, patrimonial, economic and personal elements needed to produce goods and services for the market. Instead they have become a small nucleus of patrimonial and economic elements with a minimum staff that establishes commercial relationships with other business organisations, and it is these that provide the labour required to perform their business activity. Moreover, between the business that receives services and the workers of the contractor, no contractual link or any kind of responsibility is shouldered by the principal regarding the workers who render services, more often than not in their own work centres.

These contracting companies are also characterised by carrying out an enormous multiplicity of services that grow according to "the demand" of client companies, and they barely require any material means to render them. This is when the so-called "immaterial contracts" appear, whose activity is based fundamentally on the personal element: labour. Generalisation of subcontracting has been quantitative, but also, and especially, qualitative because it has gone from the "specialisation" that characterised contracting companies' (qualified personnel; providing specialised technical means) "multipurpose aspect", to companies whose social object is continuously expanding according to the client company's demands, and neither requires complex and costly technical means, nor qualified personnel. The change in the jurisprudential criterion in identify- 
ing the collective agreement applicable to these companies ${ }^{1}$ led to intense bargaining activity in business terms which, now beyond its subsequent legal annulment and the working conditions that regulate it, demonstrates the scope that these companies have extended to, which has also reached the PTC that have constituted their outsourcing divisions because subcontracting is subject to fewer legal restrictions.

\section{Propitiatory Causes: The Law-Maker and Courts' Concurrent Faults}

Several legal causes have favoured this change in the business organisation model and the appearance of a new workers' category: "workers-out". The main characteristic of these workers is their high level of precariousness and, despite being part-time workers, they escape the traditional dual classification that compares indefinite workers and part-time ones as they even lack the minimum guarantees that protect part-time workers.

Briefly, these causes are as follows (Vicente-Palacio, 2016a):

\subsection{The Role of the Courts}

The fact that at the end of the 1990s the Supreme Court, then without any initial circumlocutions, allowed contracts and concessions, and any other circumstance that was external or unrelated to the company's activity, characterised by its uncertain continuity, to be a valid cause to sign a contract for a given work or service was doubtlessly the first step in this evolution process of the work contract model. Now it is no longer necessary for the activity to be performed by the worker, contracted for a given work or service, to be intrinsically part-time-activity ends or contracts run out after the given work is performed, as previously expected-but the subcontracting of any activity (work or service) with another company confers it the temporariness (given its uncertainty of continuing in the future) that it lacked if it had been done directly by the principal businessperson. In short, uncertainty is no longer projected on the term of the contract, but is transferred to its cause or object: the uncertainty for the employer of an activity

${ }^{1}$ This jurisprudential current regarding the validity of contracts or concessions as a cause of contracts for a given work or service can be found in STS of 15-1-1997 (RJ 1997, 497) obiter dictum, and quite clearly in STS of 8-6-1999 (RJ 1999, 5209), to continue later uninterruptedly in, among many others, STS of 20-11-2000 (RJ 2001, 1422), STS of 26-6-2001 (RJ 2001, 6839), STS of 14-6-2007 (RJ 2007,5479 ), STS of 21-2-2008 (rec. 178/2007), STS of 10-6-2008 (rec. 1204/2007). Prior to this doctrine, during the period between 1991 and 1997, the Supreme Court established the unified doctrine according to which "the express mention in the work contract of the place where services are rendered does not per se confer them the typical autonomy and substantivity expected by (...)" [see, among others, STS of 26-9-1992 (RJ 1992, 6816), and likewise STS of 17-3-1993 (RJ 1993, 1866). The Supreme Court commenced its change of course to what has ended up being its total acceptance of an intermediate doctrine, according to which such contracting was valid not on the basis of those assumed cases that given works or services constituted, but understood its valid admission as a resolution condition under the protection of Arts. 49.2 and 3 of the WS by understanding that any abuse by the businessperson would not be appreciable by introducing a clause that subordinates the contract to the maintenance of the contract or concession, an argument that is also noted and allowed by some authors of the doctrine (see STS of 28-2-1996 [RJ 1996, 2738) and STS of 15-1-1997 (RJ 1997, 497)]. 
continuing has ended up justifying the practice of engaging workers with contracts signed for a given work or service (Vicente-Palacio, 1996; Garcia Ninet \& Vicente-Palacio, 1999; Garcíaninet \& Vicente-Palacio, 2009)².

Secondly, if the flexibilisation of the causality of the work/service contract is the essential legal instrument in the business organisation model mutation, then the change in the jurisprudential doctrine on the delimitation between the illegal cession of workers (Art. $43 \mathrm{WS}$ ) and the legitimate subcontracting or work and services (Art. $42 \mathrm{WS}$ ), and on the scope of the foreseen legal guarantees for workers in assumed subcontracting cases, has served as a good incentive by minimising the principal company's responsibilities, and by making this form of business organisation more appealing.

From the traditional demand of the contracting company having an autonomous and independent organisation equipped with the material means needed to perform the contracted work or to offer the contracted services (company-organisation $)^{3}$, jurisprudence established a criterion that distinguished between subcontracting works and services and the illegal cession of workers, the contractor exercising management power along with the management inherent to the business condition (Art. 1.2 ET) ${ }^{4}$, independently of organisational size (company/activity), by understanding that what was relevant was to effectively exercise business management power. Although this was not its purpose, the effect of the cited doctrine was the jurisprudential sanction of the lawfulness of companies that render services, even when they lacked the material means needed to perform the business activity, and could thus correspond to the principal company.

To this recognition of the lawfulness of immaterial contracts, the restriction of the legal guarantees foreseen for subcontracted workers as a result of the jurisprudential interpretation of the "own activity" concept that determines the application of Art. 42WS, is also added, which imposes solidarity-type responsibili-

\footnotetext{
${ }^{2}$ This jurisprudential current regarding the validity of contracts or concessions as a cause of contracts for a given work or service can be found in STS of 15-1-1997 (RJ 1997, 497) obiter dictum, and quite clearly in STS of 8-6-1999 (RJ 1999, 5209), to continue later uninterruptedly in, among many others, STS of 20-11-2000 (RJ 2001, 1422), STS of 26-6-2001 (RJ 2001, 6839), STS of 14-6-2007 (RJ 2007, 5479), STS of 21-2-2008 (rec. 178/2007), STS of 10-6-2008 (rec. 1204/2007).Prior to this doctrine, during the period between 1991 and 1997, the Supreme Court established the unified doctrine according to which "the express mention in the work contract of the place where services are rendered does not per se confer them the typical autonomy and substantivity expected by (...)" [see, among others, STS of 26-9-1992 (RJ 1992, 6816), and likewise STS of 17-3-1993 (RJ 1993, 1866). The Supreme Court commenced its change of course to what has ended up being its total acceptance of an intermediate doctrine, according to which such contracting was valid not on the basis of those assumed cases that given works or services constituted, but understood its valid admission as a resolution condition under the protection of Arts. 49.2 and 3 of the WS by understanding that any abuse by the businessperson would not be appreciable by introducing a clause that subordinates the contract to the maintenance of the contract or concession, an argument that is also noted and allowed by some authors of the doctrine (see STS of 28-2-1996 [RJ 1996, 2738) and STS of 15-1-1997 (RJ 1997, 497)].

${ }^{3}$ Among others, see STS of 21-3-1997 [RJ 1997, 2612], STS of 14-9-2001 [RJ 2002, 582], STS of 17-12-2001 [RJ 2002, 3026]; STS of 17-1/2002 [RJ 2002, 3755], STS of 17-12-2001, STS of 30-11-2005 [RJ 2006, 1231], STS of 14-3-2006 [RJ 2006, 5230], and STS of 17-4-2007 [RJ 2007, 3173]. ${ }^{4}$ STS of 19-1-1994 [RJ 1994, 352), STS of 25-10-1999 [RJ 1999, 8152], among many others.
} 
ties in occupational and Social Security matters to the principal contractor. The Supreme Court's consideration that only those services or works that correspond to the main company's production cycle (inherency thesis) can be included in the "own activity" concept. Hence this excludes supplementary or non-central tasks, as opposed to the former "indispensableness" thesis ${ }^{5}$, which meant a new impulse for subcontracting, while the principal businessperson's responsibility for workers from the subcontracting agency was restricted to the mere subsidiary responsibility foreseen in Social Security matters (Arts. 142 and 168 of the Codifying Legislation of the General Social Security Law; CLGSSL).

Finally, exclusion through jurisprudence from the area of application in Art. 44 of the WS on subcontracting, and thus of the guarantees that this precept establishes for cases of companies changing their ownershop, has been no less important in this business organisation model. If in order to delimit the illegal cession of workers being subcontracted for works and services the Supreme Court (SC) deals with the company-activity, for company transfer issues the SC considers that Art. 44 of the WS demands patrimonial elements to be effectively transferred from a business infrastructure or business organisation no matter how minimum they are; that is, it refers to the business-organisation concept, without considering that these circumstances are combined with assumed changes in contracts, which only involves transferring the legal contractual title that guarantees the client company's activity being performed, but without the organisational complex of assets, capital and works typical of the business-organisation being transferred.

It is now true that the Supreme Court $(2004)^{6}$, by applying the EU Law Court sentence of 24-1-2002 (C51/00) (Temco case) and other sentences ${ }^{7}$, allows the application of Art. 44WS to immaterial contracts, but the Community Court doctrine's scope is very limited in that it conditions the application of community law-of which Art. 44 of the WS constitutes its implementation-to the assumption made by the new contractor of the former contractor's personnel, and this subrogation is precisely the object of legal control. So if the collective agreement does not impose transferring the personnel of the leaving contractor to the new one, the subrogation does not apply, which represents a clearly confusing cause and effect, unless the businessperson unilaterally and voluntarily takes on that personnel.

\subsection{Legislator's Role}

Resorting to the part-time workers ceded by PTC has become less appealing as a

${ }^{5}$ See a summary of both theses in STS of 24-11-1998 (RJ 1998, 4770).

${ }^{6}$ STS of 20-10-2004 (rec. no. 4424/2003). Thus it accepts the new community doctrine, the important STS (Sala General) of 29-5-2008 (rec. 3617/2006). Vid. STS of 20-10-2004 (rec. 4424/2003);STS of 21-10-2004 (rec. 5073/2003), STS of 27-10-2004 (rec. 899/2002) and STS of 26-11-2004 (rec. 5071/2003). However, sentences after the Temco Sentence continue denying the application of Art. 44WS to changes in contract assumptions and still refer to the conventional system by declaring it applicable or not to the specific case depending on whether conventional demands are met or not. See, among others, STS of 19-11-2014 (rec. 1845/2013); STS of 16-12-2014 (rec. 1054/2013).

${ }^{7}$ The Schmidt case. C-392/92, Rec. 1994) about a cleaning contract, and the Merckx and Neuhuys cases (as. ac. C-171 and 172/94, Rec. 1996), about a concession for automobile sales. 
result of the improvement made to the legal statute of these workers that derives from taking them as equal to the workers of the user company under essential working and employment conditions $(1999 ; 2001)^{8}$, considered as those that refer to remuneration, the duration of working days, overtime, rest periods, night work, workers' own holidays and public holidays; that is, those with an immediate economic quantification. Having disappeared one of the main competitive advantages for PTC, companies sought flexibility for contracting other companies to supply them with the personnel required to undertake their business activities at a set and predetermined fee, and very few companies shoulder responsibilities because the responsibilities of the principal company of the works and services that do not correspond to its own business activity, as previously stated, are considerably fewer than those imposed on the user company (Arts. 164 of the CLGSSL; Art. 14 of the Law on PTC; Art. 16.2 of the Law on PTC; Art. 16.3 of the Law on PTC), by PTC not complying with matters about the workers ceded in occupational issues, preventing occupational hazards and Social Security.

Secondly, the promoting the company as a preferential for collective bargaining has also had a great influence. The legal amendment of regulations on combined agreements (vid. supra) has also contributed to multiservice companies becoming more widespread and their workers' legal statute becoming more precarious. If jurisprudence had initially responded to that intended and deliberately sought conventional anomie by declaring the application of the sectorial agreement of the multiservice company's predominant activity, its later change of direction to the specificity or speciality criterion ${ }^{9}$ would once again balance competition among the companies that work in the same activity sector, which determined the mass signing of own agreements in these multiservice companies

${ }^{8}$ A Law 29/1999, of 16 July, which amended Law 14/1994, of 1 June, established the rights of ceded workers to be paid, as a minimum, the complete payment agreed on for the job post to be worked in the collective agreement that applies to the user company, calculated by the time unit, including the proportional part that corresponds to the weekly rest period, bonuses, public holidays and the worker's own holidays. Royal Decree-Law 10/2001, of 16 June, was that which guaranteed the aforementioned equalisation under essential work and employment conditions.

${ }^{9}$ Initially the collective agreement of the "predominant activity" was referred to [among others, STS of 10-7-2000 (rec. 4315/1999); STS of 29-1-2002 (rec. 1068/2001); STS of 17-7-2002 (rec. 4859/2000); STS of 31-10-2003 (rec. 17/2002); STS of 31-1-2008 (rec. 2604/2004); STS of 20-1-2009 (rec. 3737/2007); STS of 17-3-2015 (rec. 1464/2014)] to then apply the speciality criterion; i.e., applying the collective agreement that corresponds to the specific service that the multiservices company offers as part of the separately considered contract [of the many others that follow this criterion, we find the STSJ Galicia of 6-2-2004, STSJCastilla La Mancha of 26-7-2005 (rec. 1137/2005), STSJ Valencian Community of 9-11-2005 (rec. 1247/2005), STSJ Valencian Community of 3-5-2006 (rec. 927/2006), STSJCastilla-La Mancha of 2-10-2006 (rec. 723/2005), STSJCastilla y León of 2-10-2006 (rec. 1563/2006), STSJ Andalusia of 14-3-2007 (rec. 3041/2006), STSJCastilla-La Mancha of 15-7-2007 (rec. 696/2006), STJS Cantabria of 1-10-2007 (rec. 782/2007), STSJ Cantabria of 29-12-2007 (rec. 1063/2007), STSJ Basque Country of 11-11-2008 (1737/2008), STSJ Madrid of 20-10-2008 (rec. 2399/2008), STSJ Andalusia of 21-6-2012 (rec. 3025/2010), STSJCastilla y León of 14-4-2014 (rec. 12014), STSJ Andalusia of 20-11-2014 (rec. 2489/2014), STSJ Madrid of 24-9-2012 (rec. 2978/2012), STSJ Madrid of 8-10-2012 (rec. 2962/2012), STSJ Madrid of 24-1-2014 (rec. 427/2013), STSJ Madrid of 24-9-2012 (rec. 2978/2012), STSJ Madrid of 29-10-2012 (rec. 4321/2012), STSJ Madrid of 30-1-2012 (num. rec. 3572/2011). The performed activity must be accredited by someone who alleges the application of another different agreement to that indicated in the work contract (STSJ Asturias of 17-5-2013 (rec. 732/2013); STS of 28-6-2013 (rec. 1076/2013). 
with clearly poorer working conditions than those set out in sectorial agreements. If we leave to one side the legal annulment of most of these agreements due to there being no correspondence between their functional domain and the social bank that negotiates them, what is true is that it was the priority applied to the company collective agreement, through the reform made with Law 3/2012 - then unassailable for agreements from a superior domain (VICENTE-PALACIO, 2014)-, which allowed these companies to be removed from many sectorial agreements that applied to them in all the activities undertaken for their customers. The consequence was a questionable "normative diversity" of the workers of these companies, depending on the activity they were assigned to at each time. The doubtless advantage was better working conditions were being negotiated in sectorial terms and, therefore, by the most representative trade unions (Art. 87.1. WS).

The collective agreement of company became orchestrated to evade sectorial, but more guaranteed, regulations by these companies recovering the competitive advantage that had been lost by applying the speciality criterion when identifying the applicable sectorial agreement as these company collective agreements set out worse job conditions, much worse than those enjoyed by the workers subject to the corresponding sectorial agreement. This generates a new worker category, and one characterised by its extreme precariousness: "sub-ceded workers", whose weakness is demonstrated in all their working conditions.

\section{Consequences: Increased Precariousness and the Appearance of the "Sub-Ceded Worker"}

The intention of this name ("sub-ceded") is to be assigned to workers who, through this legal interposing phenomenon, find themselves in a clearly inferior situation than the workers ceded by PTC to render services in user companies, and also to those workers who belong to the contracting companies that provide their principals their added value of their personnel's specialisation, as well as contributing the material means needed to perform this activity. The "sub" prefix thus acquires two potentials: on the one hand, to underline the pejorative working conditions of the workers of these multiservice companies; on the other hand, to link it to the form of business organisation that allows it (subcontracting). For most of its meanings, the term "ceded" mainly reflects this loss of position, relinquishment, submission or the inferiority that actually characterises these workers ${ }^{10}$.

In short, sub-ceded workers' precariousness is displayed in all the phases of their work relationship and in all their working conditions as follows.

\footnotetext{
${ }^{10}$ The Royal Spanish Academy Dictionary: "Ceder/Cede": 2. tr. Lose time, space, position, etc., to a rival; 4. intr. Relinquish, submit; 5. intr. Regarding wind, fever, etc.: mitigate, lose one's strength; 6. intr. Stated of something: Diminish or cease one's resistance; 7. intr. Stated of something submitted to excess force: Break or break loose; 8 . intr. p. us. Stated of something or someone: inferior to another that it/he/she is compared with.
} 


\subsection{Admission and Contract Termination}

As previously pointed out, workers are admitted to the company via a contract signed for a given work or service. Thus workers are part-time and whether their work relationship is maintained depends on the contract continuing, whose expiry occurs when the set condition arrives, and determines the automatic termination of the contract for the given work and service. Moreover, the new contractor is not obliged to replace the former contractor's work contracts, unless the collective agreement imposes this replacement obligation in its own terms, which do not necessarily have to coincide with statute-related regulations (Art. 4 WS). These replacement mechanisms are contemplated in some (a few) sectorial agreements, but as they are not applied by negotiating the company collective agreements that do not plan them implies that these workers are exposed to their contract expiring, even though these contracts maintain the subcontracted activity with another contractor. Although the Supreme Court still does not allow the total or partial anticipated resolution of the contract of service as an automatic cause for a contract to terminate-a case that must address economic, technical, organisational or production causes (Arts. 51 and 52.1.c) WS)-, there has still been no announcement about unifying the doctrine about the lawfulness of the very frequent ${ }^{11}$ conventional clauses that justify the automatic resolution to not indemnify work contracts in those cases in which the contract of service is terminated in advance through the customer's will, a possibility that some high Courts of Justice have accepted ${ }^{12}$.

\subsection{Contract Execution}

Collective agreements of multiservice companies-negotiated by questionable workers' representatives (normally "independent") and in record times (sometimes they are signed the same day they are constituted on the bargaining table)-, establish working conditions that are quite inferior to both those applied to the workers subject to different sectorial agreements that may possibly apply

${ }^{11}$ Among many others: C.C. Avantia Outsourcing S.L (Res. Of 25-10-2013) [BOPA of 5-11-2013]; C.C. Aditia Outsourcing, S.L. (Res. Of 27-8-2013) [BORM of 12-9-2013]; C.C. Lloyd Outsourcing S.L (Res. of 25-6-2012) [BOE of 9-12-2012]; C.C. Citius Outsourcing S.L (Res. of 21-9-2012) [BOE of 5-10-2012]; C.C. Risk Steward S.L (Res. of 18-1-2013) [BOE of 4-2-2013]; C.C. Merchanservis S.L. (Res. of 7-3-2014) [BOE of 21-3-2013]; C.C. Rango 10, S.L (Res. of 25-4-2013) [BOE of 10-5-2013]; C.C. Alliance Outsourcing S.L. (Res. of 14-6-2013) (BOE of 1-7-2013]; C.C. Iman Corporation S.A (Res. of 14-6-2013) [BOE of 4-7-2013]; C.C. CPMExpertus Field Marketing, SAU (Res. of 5-12-2013) [BOE of 19-12-2013]; C.C. RepomarketSLU (Res. of 19-12-2013) [BOE of 3-1-2014]; C.C. AlternaBPO (Res. of 7-11-2014) [BOE of 21-11-2014]; C.C. SerlimarServiciosAuxiliares, SL (Res. of 26-5-2014) [BOP Barcelona of 11-7-2014]; C.C. Serveis Integrals Linda Vista, SL (Res. of 15-1-2014) [BOP Barcelona of 7-4-2014]; C.C. ExpertusServicios de Atención al Público, SAU (Res. of 20-11-2013) [BOP Barcelona of 28-2-2014]; C.C. CPMExpertus Field Marketing, SAU (Res. of 5-12-2013) [BOE of 19-12-2013]; C.C. ExpertusServiciosHoteleros, SL. (Res. of 11-4-2013) [BOE de 25-4-2013]; C.C. Adecco Outsourcing SAU (Res. of 18-5-2015 [BOCA de 11-7-2015]; C.C. Alianzas y Subcontratas, SA (Res. of 20-7-2015) [BOE of 6-8-2015];

${ }^{12}$ Among others see, STSJ Andalusia of 23-9-2015 (rec. no. 2281/2014); STSJ Madrid of 4-3-3011 (rec. no. 5879/2010); STSJ Madrid of 4-2-2011 (rec. no. 5300/10); STSJ Catalonia of 23-1-2008 (JUR 2008, 106385), STSJ Catalonia of 14-2-2008 (AS 2008, 1320)]. 
and all their issues (salary, reevaluating salaries, annual working days, irregularly distributed working days, working days, public holidays, workers' holidays, complementary Social Security, etc.). In general terms, the business management's power being reinforced is appreciated when clauses that enable the company to amend working conditions are foreseen, supported by the fact that the customer's demands are a determining organisational cause for Art. 41 of the WS being applied ${ }^{13}$.

\subsection{Strike Right}

Problems may arise when considering the right to go on strike (Art. 28.1. EC) when the contractor's workers exercising this right results in the anticipated resolution of the contract of service taken by the principal because of breach of contract, and contracts are subsequently terminated. The legal doctrine allowed these contract terminations to be lawful and, although the Constitutional Court granted the requested protection (STC 75/2010, of 15 October), there were many dissenting votes against it. This demonstrates the legal problems that this triangular relationship of services has, plus the need for the lawmaker to urgently intervene.

\subsection{Precariousness in Preventive Matters}

Sub-ceded workers are also exposed to. There is a huge difference between the obligations and responsibilities imposed on PTC and those that reach contracting companies (Vicente-Palacio, 2016b) ${ }^{14}$ and far fewer reach the latter. One significantly aspect that whereas activities and jobs which, given their particular hazardous nature, are excluded from signing contracts between a PTC and the user company (D.A. 2nd Law of PCT, and in what is not opposed to this practice in its wording set out in Law 35/2010, of 17 September; Art. 8 RD 216/1999), no such foresight exists in the subcontracting domain, which can affect any activity, be it with the caution that Law 32/2006, of 18 October, on subcontracting in the Building Sector, establishes for the simultaneous occurrence of notes that characterise a company as an owner of its productive organisation which, apart from taking the typical risks of undertaking its business activity, directly exercises organisation and work management faculties.

Furthermore, collective bargaining in multiservice companies is still far from serving as a channel to set up procedures or systems that allow their workers' occupational hazards to be improved or examined in more depth. Their preven-

\footnotetext{
${ }^{13}$ For the time being, the scarce legal doctrine that has dealt with the theme rules out that the mere fact that the customer wishes to amend the way to render services may be set up as organisational or production causes, which would only occur when organisational or production reasons coincide unexpectedly in the principal company [STSJ Basque Country of 2-12-2014 (rec. no. 2283/2014)]. ${ }^{14}$ On this matter, for further details see, VICENTE PALACIO, A., "Prevención de riesgoslaborales: empresasmultiservicios vs. Empresas de trabajo temporal", in AA.VV (Dir. TOSCANIGIMENEZ, D., \& ALEGRE NUENO, M.), “Análisispráctico de la Ley de Prevención de Riesgos Laborales”, Lex Nova, 2016.
} 
tive content is either virtually nonexistent or does not distinguish from the cautions normally found in the agreements of companies that do not normally subcontract; that is, the basic fact that characterises business activity is ignored, this being rendering services in work centres other than their own, and the increased accident and/or claims rate that derives from subcontracting, and from the part-time work that generally characterises the contracts of these companies' workers (Arts. 24 and 28 Law on Protection against Occupational Hazards; LPOH).

\subsection{Social Security Questions}

In line with Social Security matters, the sub-ceded worker's precariousness can also be verified: low salaries affect their Social Security payments, and therefore their future regulatory bases, to which it is necessary to add any irregularity and/or discontinuity of their careers to their Social Security payments, which will make it more difficult to accredit increasingly demanding grace periods to be able to access retirement. All this takes place at a time when public protection in the future will quantitatively diminish as a result of the reforms made in recent years.

\section{On the Possibility of Reversing Precariousness}

\subsection{A Judicial or Legal Solution? The Difficulty of a Solution by Collective Bargaining}

As pointed out, it seems undeniable that the generalisation of outsourcing through multiservice companies has increased sub-ceded workers' occupational precariousness because, in today's regulations, they cannot count on the instruments to guarantee their occupational rights: they are left with only judges' intervening in individual and collective conflicts, which has, to date, allowed to place a limit to what has become one of the most recent manifestations of the so-called "fleeing from the Employment Law": the appearance of multiservice or all-round management companies. As the role played by the legal doctrine and jurisprudence is important, it seems that the solution to some problems that stem more from lacking suitable normative instruments than from their application or interpretation, this being precisely the object of jurisdictional tasks, must not be delegated to these companies (Art. 117.3 EC). Some legal solutions, whose purpose is still commendable, are legally questionable and, in the meantime, multiservice companies penetrate increasingly further into the market, accompanied by seriously precarious work. It would seem, however, that Trade Unions can and must play a more leading role to fight against this fleeing from the Employment Law, which is creating a new labour market segmentation and, although they cannot substitute the lawmaker, one cannot deny that Trade Unions have a certain margin to act in that goes well beyond the mild terms in which this reality is referred to-with a very limited scope-in the Agreement for Em- 
ployment and Collective Bargaining 2015-2017 ${ }^{15}$ : the search for greater Trade Union implementation in these companies and work centres to allow bargaining of business agreements with better working conditions, basically in matters of salary and working hours, to avoid these forms of rendering services cutting their social costs, which is one of their most appealing aspects and, above all, to encourage sectorial bargaining by ruling out, whenever feasible, the participation of Trade Union organisations in negotiations of business agreements when it is a true obstacle to reach such agreements if their purpose is to hinder sectorial collective agreements with more guarantees being applied. Moreover, objections are being made to the employment authorities (Art. 165 LJS) of these collective business agreements by those who do not legally fulfil that expected in the area covered by the agreement. Apart from these Trade Union strategy measures, in business terms it is also possible to act in the conventional regulation area in many aspects, where referring to the sectorial agreement is particularly important as an extra right, as is foreseeing the application of the sectorial agreement's salary system and working day, unless the company's agreement establishes a more beneficial system, which is not usually the case.

Although collective bargaining is important, it cannot replace the lawmaker: it is the lawmaker's competence to adapt instruments to guarantee workers' rights to multiservice companies' new realities and to establish new protection mechanisms by legislating wherever conventional regulations do not reach, especially when this cannot impose obligations to those who did not form part of the bargaining process and remain, therefore, beyond the area to which the agreement applies. The delegalisation to favour collective bargaining of the 1990s, along with the more recent promotion of the company as a preferential bargaining unit, plus lack of foresight of mechanisms to allow the inconveniences that stem from lack of legitimisation for Trade Union organisations' business collective bargaining to overlap, indicate that the current Employment Law does not work to efficiently protect workers' rights.

The lawmaker can intervene from several positions: by acting on the causes that have favoured the multiservice companies phenomenon as an outsourcing system, based exclusively on acquiring competitive advantages by making employment precarious; legislating to mitigate some of the most harmful consequences of outsourcing wherever collective bargaining cannot reach given its li15 “ j) On the subcontracting and the productive outsourcing and substitution of activities, employment and working conditions, given the importance and scope that various forms of productive and societal organisation forms acquire in a growing context of business outsourcing activities which has given rise to legal regulations that establish information rights to represent workers, those who sign the present agreement consider it necessary for collective bargaining to help facilitate compliance with that set out in Art. 42 of the WS. This will lead to safe employment and will help the working conditions set legally and conventionally to be met. The representative capacity, and the area to act in, of workers' representatives, as well as their time-credit for Trade Union activities, will be determined by the legislation currently in force and, if applicable, by the applicable collective agreements. In line with this, both business and Trade Union organisations share the notion that the new productive and societal organisation forms, which often prove most complex, must not imply not applying the corresponding conventional regulation, nor the illegal cession of workers". 
mited scope of application, which is becoming increasingly fragmented by promoting the company as a preferential bargaining unit. Undoutedly, outsourcing can be a legitimate form of business organisation through the flexibility that operating with simpler business structures implies, which provide a specialised labour added value and, if applicable, the exact "organisational structure". However, when neither one nor the other coincides, labour regulations must react by covering the cracks that allow their tuitive regulation to escape.

The Administration also has a key role to play, particularly the competent Employment Authority, which must carry out effective control prior to the agreements that are presented to be left and published (Art. 90.2 WS), especially the collective agreements of multiservice companies because, having completed all the formal proceedings in Art. 90 of the WS, the collective agreement is favoured by its assumed legitimacy. This legality assumption is also binding, and it particularly binds the Labour Inspection by limiting its possibilities to act, and can only be destroyed by the corresponding legal authority if demanded by the legitimate parties or, if it were the case, by virtue of any official communication by the Employment Authority (Art. 163 and following Arts. of Law on Social Jurisdiction). The fact that the regulating role of statute-related collective agreements has increased with deregulation-along with the aforementioned the company's (statute-related) agreement being preferentially applied-and determines the regulation framework within which the Labour Inspection must evaluate if the lawfulness in force is being fulfilled, is determined precisely by this collective agreement.

Even when all formal proceedings have been completed, except for the official publication, the Inspection's facultites to face any possible lawfulness doubts are limited, once their presentation to be registered before the Employment Authority has been verified, to the suspension of inspectors' actions until the Employment Authority has solved the matter.

Some of the proposals offered below include nuances, and can even be combined in different ways, and grouped into various "packages" but, after analysing them, could be a good starting point to arbitrate effective normative solutions, solutions that do not seem to require any specific regulation for outsourcing activities, save the provision of the specific instruments by which common occupational regulations are constituted: the Workers Statute (WS): the opposite implies a new disintegration of labour regulations.

\subsection{About Contracts of Operative Workers}

A good starting point to put a stop to these companies' expansion in exchange for precarious employment might be to redirect contracts for a certain work or service to "intrinsically part-time activities" or, in other words, not allowing the contract of service or concession as a "part-time" cause that justifies signing the contract for the given work or service. It does not seem acceptable that as the sole business activity of some companies is to render services to customer com- 
panies and, thus, their activity always depends on a former commercial or administrative relationship, their personnel may be made up exclusively of part-time employees. Labour regulations have enough mechanisms to cancel work contracts in the assumed case that the company loses the contract or concession: individual [Art. 52.1.c) ET] or collective (Art. $51 \mathrm{ET}$ ) dismissal for economic reasons. This not only allows workers access to more redundancy payment in assumed cases when contracts are cancelled, but also to other forms of protection from which they are now excluded through the "natural" way of cancelling their contract: e.g., the possibility of accessing early retirement for a reason that cannot be attributed to the worker (Art. 207 CLGSSL). Apart from this allowing better access to early retirement than that foreseen for this purpose through the worker merely wishing to retire early (Art. 208 CLGSSL), it also foresees less penalisation for early retirement for such early access. There is also the obligation to finance the special agreement on cases of redundancy measures that affect workers over the age of 55 who are not workers' friendly society members as of 1-1-1967 (Art. 51.9 WS and D.A.13a CLGSSL) or, if appropriate, companies that make profits paying the Public Treasury and that make collective dismissals which affect workers over the age of 50 (Art. 51.11 WS and D.A.16 Law 27/2011).

Along the same lines, and despite jurisprudence already maintaining a clear posture that excludes the possibility of automatically transferring the total or partial early cancellation of the contract of service or concession to the work contract, in many agreements this circumstance has been regulated as a legal cause to cancel contracts, which must clearly be excluded: if jurisprudence has still not covered the matter when unifying the doctrine, it has been exclusively due to the fact that the necessary requirement of this contradiction is lacking. However, the same solution must doubtlessly be applied when nothing is available conventionally: the impossibility of the total or partial cancellation of the contract of service automatically affecting the work contract and determining its cancellation. Indeed better control by the Employment Authority of the lawfulness of the contents of collective agreements is missing because such a conventional clause being considered a valid resolution condition is clearly illegal as it directly implies undermining the legal system to cancel contracts, which is clearly a necessary right that is unavailable.

\subsection{The Non-Restriction of Article 42 WS to the Contracts of Service That Correspond to the Main Company's Activity and Other Proposals}

The lawmaker must extend the solidarity liabilities system set out in Art. 42 of the WS to all the contracts and subcontracts of service that correspond, or not, to the principal businessperson's activity. Article 42 of the WS acts as the main instrument to guarantee subcontracted workers' employment rights and its restriction to those that correspond to such activity do not provide them with pro- 
tection in particularly delicate matters, like wage debts and Social Security liabilities. Nowadays as far as wage credits are concerned, beyond the framework of Art. 42 WS, the client company lacks any form of liability-and, evidently, also in relation to any other debt the contractor may hold with his/her workers-and in Social Security matters, and only shoulders a subsidiary liability for Social Security benefits for which the contracting company may be responsible for not fulfilling its obligations in workers' being registered and making Social Security payments (Art. 167 CLGSSL) and contribution amounts paid (Art. 142 CLGSSL) while the contract is valid.

These very few liabilities that the client company must shoulder as part of the subcontracting system contrast with the liabilities attributed to the user company as part of its relationships with PTC, and this legal system is based on the convenience of implying whoever receives a ceded worker's services in the triangular relationship. Subcontracting also constitutes de facto a relationship with three personal elements, and it is not too far-fetched to match the liability scheme of both customers: the main company and the user company, and even raise this liabilities system.

It is well-known that the user company is the solidarity responsible party when ceding workers in assumed forbidden cases (Art. 16.4 Law PTC) - just as the client company can be classified as an illegal cession in subcontracting (Art. $43 \mathrm{WS}$ ) - and is the subsidiary responsible party in salary matters, and for the redundancy payment that derives from cancelling a work contract (Art. 16.3. Law on PTC). Meanwhile in subcontracting, a solidarity liability operates in salary and Social Security matters (amounts paid and benefits), but exclusively when the contract of service corresponds to a firm's own activity, which does not tend to take place in the multiservice companies domain. Eliminating this restriction would allow the client company's liability to become considerate in salary and Social Security matters for all contracts of service, and it would also be convenient to extend the solidarity liability to the redundancy payment made when the contract ends, and even to non-wage-based debts or, if applicable, to foresee a subsidiary liability for such matters by matching the liability in this matter to that demanded of user companies.

Moreover, extending the area that Art. 42 WS covers to all contracts of service, regardless of them corresponding to the main company's business activity or not, must also reach any increase in benefits made for omitting security measures, and the lawmaker must expressly decree it as such because nowadays it being extended to the main company, provided that services are rendered in its work centre or in the production facilities controlled by the main company, is the result or the consequence of today's legal interpretation, provided that it is subject to its usual vicissitudes. And so it is that a coincidence exists with that set out in the part-time work triangular relationship, where the user company is liable for any increase made in benefits when an accident occurs in the work centre (Art. 16.2 Law on PTC), although this match is not legally considered. 
As regards prevention matters, the main obligations imposed on the main businessperson and that benefit workers, are restricted to the contracts of service that refer to his/her own business activity. This is what firstly happens with the supervising duty, which the main businessperson must deploy to see if his/her contractors comply with regulations on preventing occupational hazards (Art. 24.3 LPOH and Art. $10 \mathrm{RD}$ 171/2004, of 30 May), which is restricted to the contracts of service that correspond to his/her own activity, and are also carried out in his/her work centre. The location restriction seems reasonable as it is the space which the main businessperson controls and supervises, but not for those that correspond to the business activity itself: the supervising duty must include all contracts of service, regardless of them corresponding or not to the main company's business activity. Secondly, the main businessperson's solidarity liability as to him/not fulfilling the obligations that the LPOH imposes on him/her (Art. 42.2 LPOH) must also, and with a logical connection, include all contracts of service, regardless of them corresponding to the business activity or not.

Extending the system indicated in Art. 42 WS to all contracts of service will also entail extending the main company's administrative liability as to the contractor's non-compliances classified in LISOS (Law on Offences/Sanctions in Social Order) as the vast majority of currently classified assumed cases are classified as such thanks to Art. 42 WS. Therefore, the administrative liability as regards sanctioning matters is restricted to those contracts of service that correspond to the main company's business activity.

However, this does not appear to be the way by which future reforms can move along. The Draft Bill, presented by the $\operatorname{PSOE}^{16}$ (the Spanish Socialist Worker's Party) for the reform of Art. 42 WS to improve subcontracted workers' legal statute, is still anchored to those contracts of service that correspond to the client company's business activity and takes the restricted definition of this activity, which jurisprudence has maintained for years: "when it corresponds to all or some of the main activities or its [the contracting businessperson] central one, and it implies the contractor or subcontractor contributing labour to perform professional tasks directly related with these main or central activities."

\subsection{Applying the (Legal) Company Subrogation in Assumed Cases of Transferring Administrative Contracts of Service and Concessions}

The business subrogation is also an essential element to ensure workers' rights, particularly the continuation of those workers linked to the contract of service or concession that renders services in the assumed cases in which the contractor or concessionaire is changed in order to cushion the precariousness of the contractual link's part-time nature. Moreover, it being applied to these cases helps neutralise the "part-time nature" argument of the business requirement, which has been used as a causal justification for the contracts signed for a given work or

${ }^{16}$ The Official State Gazette of the General Courts (House of Commons), 12th Term of Office, Series B (Draft Bills) of 9 September 2016. 
service. The fact that in those sectors in which the outsourcing of productive activities commenced (vigilance and security; cleaning buildings and shops) subrogation was conventionally available for any assumed cases of changes being made to the contract of service or concession, and as these mechanisms have worked absolutely normally to date, demonstrate that no "technical" impediment exists for it being applied to subcontracting activity when a sectorial agreement exists that establishes it. However as previously indicated, the generalisation of collective bargaining at the business level in the multiservice companies field has further complicated subrogation in these cases being applied by excluding its application in these activities, which were formerly controlled by sectorial agreements, where it applied.

Nor can a response come from foreseeing subrogation mechanisms in collective agreements, or from client or multiservice companies, if they are indeed remotely interesting in establishing them. The correspondence principle that governs statute-related collective bargaining determines the impossibility of applying the collective agreement to those not represented by those that form part of this agreement. Thus the subjects legitimised to negotiate at the business level-a unitary representation of the work centre, or if applicable, Trade Union sections, but provided that the majority of the company's committee members or personnel delegates add up-prevent the company's agreement acting as a way out. If the legal solution foresees subrogation-type mechanisms by considering the sectorial agreement applicable, it is legally questionable as it starts from a former premise that is clearly voluntaristic: the non-control of a subrogation-type mechanism in the business agreement is a conventional gap that determines the general clause of the supplementation to statute-related regulations being applied, and ignores if this conventional omission is probably deliberated.

Nor can subrogation derive from applying the well-known Temcodoctrine which, according to Uróboros, concludes the questioned premise: i.e., the application of the system in Art. 44WS is fitting if an effective "personnel subrogation" takes place or, in other words, the personnel subrogation is the condition of the "activity subrogation" that determines whether we face a "company's subrogation" according to that set out in Art. 44WS. Conditioning the application of Art. 44 of the WS so that the collective (sectorial) agreement foresees subrogation-type mechanisms, therefore, implies new delegalisation that can be corrected only when the lawmaker applies Art. 44 of the WS. This article constitutes the national transposition of the Directive to the assumed "company transmission" cases, where the company is understood not so much for its "business organisation" sense, conferred from material means, as for it setting up management power, but also from its "organisational" aspect, which has been firstly played down jurisprudentially, followed by that which typical lies within the framework of differentiation between workers' illegal cession and lawful subcontracting.

Moreover, maintaining the contractual relationship in assumed cases of con- 
tractor or concessionaire changes will help those workers whose contracts are suspended and have no right to keep their job posts to maintain their work contract because it allows workers to join the new contractor when vacant job posts become available. Conversely, workers' right to maintain their job post is merely a hope.

\subsection{Trade Union Elections: The Need to Overcome the "Work Centre" Category in Multiservice Companies and Other Questions}

Regulations on Trade Union elections also require being reformulated to adjust them to the reality that corresponds to multiservice companies. It is true that the obligations for subcontracting information have improved in recent years (numbers 3, 4 and 5 of Art. 42 WS) and, even under certain conditions, subcontracted workers' representative faculties have been attributed to the client company's unitary representation (Art. 42.6 WS). Unfortunately, none of this has helped to elect those who represent workers in multiservice companies. The fact that the electoral unit is the work centre and not the company (despite legal diction), and multiservice companies operate in several provincial areas, save the problems that emerge in collective bargaining matters-which can, however, be solved by the form indicated in the next epigraph-make the unitary representation election in multiservice companies extremely difficult. Moreover in some cases, the undue identification between "work centre" and "workplace" has also contributed to this problem.

Several solutions can be arbitrated, but they must all intend to facilitate unitary representation mechanisms becoming available for workers in multiservice companies: indeed the lawmaker would introduce solutions that have not been tested in other areas; e.g., in the maritime domain, it is possible to consider the whole fleet to be an electoral unit regardless of the number of vessels, in the aforementioned terms and conditions. Logically, the lawmaker will have to foresee solutions to certain situations that will inevitably take place: merely by way of example, partial elections possibly being organised in the assumed cases of new contracts that determine a considerable increase in the company's number of workers or, conversely, like losing a representative through subrogation if the contractor changes, among many other assumed cases.

\subsection{Multiservice Companies and Collective Bargaining}

Without prejudice to the amendment made to regulations on Trade Union elections facilitating the existence of a representative unitary representation of all the workers of a given company to lead to a collective business agreement being applied to all the workers of a multiservice company, the lawmaker must also act on legal regulations as far as collective bargaining is concerned. As we have previously seen, in those cases for which no business agreement exists, the specificity principle determines the application of the sectorial agreement which cor- 
responds to the activity that the sub-ceded workers in the client company carry out, and although this solution may appear preferible to applying a company agreement which, as pointed out, tends to foresee pejorative conditions compared to the sectorial agreement, it generates a regulation-type diversity in both the multiservices company and possibly the client company that could have a company agreement with more beneficial conditions than the sectorial agreement offers. Moreover, it is not possible to apply the sectorial agreement in many cases because it does not exist, or because problems with identifying or appointing the activity undertaken by sub-ceded workers are considered.

Without prejudice to the aforementioned solutions that may stem from collective bargaining, the lawmaker should allow the client customer's collective agreement to be applied at least to some essential conditions, and in the same terms in which it is foreseen in PTC when the contract of service corresponds to the principal company's activity. This would do away with one of the main claims made when resorting to such companies: that of making services cheaper by worsening workers' working conditions, unless the company's agreement establishes more advantageous conditions, especially as regards salary and working hours (the working day in particular). Unlike the previously proposed generalisation of the system of liabilities set out in Art. $42 \mathrm{WS}$ for all contracts, here this proposal is limited to the contracts of service that correspond to the client company being reasonable as it is a matter of balancing or levelling the conditions in which competition in the same activity operates. However, the disadvantage lies in the inconvenience of it ending up determining this solution as not being operational in multiservice companies because, as we have seen, they tend to render supplementary or auxiliary activities. Thus in such cases, the sectorial agreement about the activity that workers perform or the business agreement must come into play if it provides more advantageous conditions.

Precisely to avoid business bargaining being used unfairly to avoid the sectorial agreement or, if it were the case, the client company's agreement being applied as a way to make labour costs cheaper, it would be worthwhile amending legal regulations for business bargainings by legitimising lawful Trade Union organisations to negotiate at the suprabusiness level similarly to that set out in the PTC domain, but by ruling out their subsidiary nature as regards the unitary representation that Art.13 of the Law on PTC guarantees. Indeed the lawmaker has foreseen special regulations for the collective bargaining of groups of companies, and also for "a plurality of companies linked for organisational or production reasons, and nominatively identified in their area of application" (Art. $87.13^{\text {rd }}$ paragraph, WS) by referring to the subjects legitimised for sectorial bargainings. Thus it would appear that there is no problem for applying the same solution to multiservice companies: in this way, it could be applied to all the valid contracts of service that the company may have when the agreement is made and to those that could be agreed on while the contract is underway by extending guarantees to all workers. 


\subsection{Multiservice Companies and Social Security}

The lawmaker must also reflect, and arbitrate solutions if necessary, on the consequences that precariousness entails for Social Segurity issues: on the system's income and expenses, and on workers' "precarious" social protection. Although this situation is not confined to only multiservice companies, such companies are the most novel source of precariousness with the peculiarity of them doing so in a generalised manner by binding the contracts of their operational personnel, i.e., practically all their personnel, to their client companies' contractual relationships. Despite the fact that the rupture of this harmful causality is proposed herein, if it was maintained by the lawmaker not acting, or if this practice found another real way to achieve the same identical objective, it would be worth considering increasing the Social Security payments of these contracts, and not unemployment fees-which is currently the case-, but a specific precariousness fees that also affects what most Social Security constitutes (common contingencies and professional contingencies): as to the latter, statistical data demonstrate a higher rate of accidents/claims for subcontracted workers, while the application of the "temporiness rate", as proposed below, would serve for financing for common contingencies.

From the workers' perspective, it is worth reflecting on the chance of establishing a "temporariness rate", similarly to the part-time rate that is applicable to part-time workers, which could curb the negative consequences that careers which involve irregular insurances have on access to and the amount of benefits for (all or some) these workers, especially those requiring longer grace periods, or by even limiting it exclusively to retirement pensions. Indeed the aforementioned additional payment of the "continued temporariness condition" could be adopted as payments to finance the economic consequences that derive from this "faciliting" access to retirement pensions by the workers exposed to today's new legal ways to evade occupational guarantees.

\subsection{Other Matters}

It would be interesting if the CNAE (Spanish National Classification of Economic Activities) would include multiservice or all-round management companies in a single epigraph, just as the Tax on Commercial and Professional Activities area does, and like the situation in 1992 did (General Law on State Budgets, 1993): this would facilitate the follow-up of business collective bargaining, and would serve to really know the extent to which these companies have penetrated the market. They would have no consequences for payments for professional contingencies because when the company performs different activities, the need to assign different Payment Account Codes is foreseen to pay for each activity, according to the epigraph that corresponds to the activities actually carried out (D.A. 4th Law 42/2006, of 28 December, on General State Budgets for 2007, with which the Rate of Bonues for Social Security Payments for Occupational Accidents and Professional Diseases was passed). Nonetheless, it would not be a bad 
thing if the cited regulation would expressly cite it being applied to multiservice or all-round management companies.

Another recommendation would be if the competent Employment Authority really controlled the lawfulness and harmfulness of collective agreements (of these multiservice companies) to which Art. 90.2 WS applies, as all the formal proceedings set out in Art. 90 WS have been finalised, the agreements are favoured by the presumption of legality. Such a presumption considerably limits the actions that the Labour Inspection can carry out, even though it may consider this agreement to not be lawful: the possibility of adopting any sanctioning file, or proceedings to possibly pay contributions, given deficiencies in the agreement for the legal framework to perform the inspection task as that set by the collective agreement would be excluded. Its possibilities to act would boil down to, in this case, as the Head of Inspection sends its objections to the Territorial Management Area which, if applicable, makes them known to the Employment Authority according to that set out in Art. 163 Law on Social Jurisdiction.

\section{Acknowledgements}

Research into multiservices companies has been done as part of the MINECO Research Projects "Rethinking Social Security" in the face of the employment crisis (DER2013-46905-P) 2014-2017 (PIs: I. Ballester Pastor and A. Vicente Palacio) and "New ways to access work" of the Universidad Jaume I-Castellón Research Promotion Plan (2015 Call) (PI: S. RuanoAlbertos).

The presented version is a re-writing of the oral version of the Speech presented at the 28 Catalan Social Law Conferences (16-17 February 2017), organised by Asociación Catalana de Iuslaboralistas.

\section{References}

Vicente-Palacio, A. (1996). El contrato para obra o serviciodeterminado. Valencia: Tirant lo Blanch.

Garcia Ninet, J. I., \& Vicente-Palacio, A. (1999). El contrato para obra o serviciodeterminado. In AA.VV. (Ed.), La contratación temporal. Valencia: Tirant lo Blanch.

Garcia Ninet, J. I., \& Vicente-Palacio, A. (2009). El contrato para obra o serviciodeterminado. In AA.VV. (Ed.), La contratación temporal y medidas de fomento de empleo. Barcelona: Atelier.

Vicente-Palacio, A. (2016a). Empresasmultiservicios y precarización del empleo. El trabajador sub-cedido. Barcelona: Atelier.

Vicente Palacio, A. (2016b). Prevención de riesgoslaborales: Empresasmultiservicios vs. Empresas de trabajo temporal. In AA.VV (D. Dir. Toscanigimenez, \& M. Alegre Nueno) (Eds.), Análisispráctico de la Ley de Prevención de Riesgos Laborales. Lex Nova. 